characters. Though the Linnean Society's discussion was held nine years ago, the idea of the establishment of national parks in Britain has gained ground and several important reports have been published since. These are discussed by Dr. Herbert Smith in the article published in this issue.

It is well that in a small country such as Britain the conception of the form and function of national parks should be thoroughly discussed before any large-scale plans are formulated and then put into effect. As Dr. Smith points out, Britain has a beautiful landscape varying considerably in character ; in fact, the variation itself is worthy of note. So to preserve this for posterity the establishment of national parks is essential. In the discussions and reports so far published, Nature preservation and respect for geological monuments loom large; but in the latest report, that of the National Parks Committee of the Ministry of Town and Country Planning recently published, it is emphasized that the function of national parks should be "more the spiritual and bodily refreshment of the people, especially the inhabitants of eities and towns, than the protection of wild life". Furthermore, considerable tact and caution are necessary when deciding what priority or privileges should be given to bona fide students of natural history over the general lay public. For example, complaint has already appeared in the newspaper press about the closing of Flatford Mill (immortalized by Constable) to the general public in favour of students. No matter what facts lie behind the acquisition of any monument, it is desirable that public opinion be taken into full consideration before final policy is settled, especially since it seems to be agreed that spiritual and bodily refreshment of the general public is of paramount importance. In other words, the authorities who have the final say in choosing and administering national parks should aim at preventing different interests from becoming clashing interests and so conflicting with each other. On the contrary, they should aim at utilizing such parks as places where not only may each interest be satisfied so far as is commensurate with the common weal, but also where one interest can meet the other to the benefit of both-a symbiosis of interests.

Thus might become established that nucleus of biological service, as Dr. Smith envisages and Dr. E. Hindle in his presidential address to Section D (Zoology) of the British Association meeting at Dundee this year pleaded for, which would offer the best field opportunities for the natural historian working among the lay public, who would conceivably watch his work with interest. Here would be an arena where work and play could move together hand in hand.

Difference in character must also be taken into account. A park in the Scottish Highlands would be unlike one in the Lake District, and again very different from one on the rolling downs of the south of England. This would need serious consideration when deciding on organisation and personnel for administration and control.

\section{SCIENTIFIC AND TECHNICAL BOOKS}

$\triangle \mathrm{S}$ one of the measures for reducing British A expenditure in countries in the 'dollar area', it has been announced that restrictions are being imposed on the importation into Britain of books. At a time when emphasis is being placed increasingly on the importance of international understanding, it is most unfortunate that this particular medium should have been selected as a means of effecting economies; books are surely one of the best means of making one people acquainted with another. Here we are concerned mainly with scientific and technical books, and the restriction will in practice apply chiefly, though not entirely, to American books. The position is that scientific and technical books may no longer be imported except under individual licence. British publishers have to submit to the licensing authorities evidence of the value of their pre-war imports of such books, and they will be given a licence to import foreign books to the same annual value. Thus we return, at a stroke, to the maximum war-time restrictions. Publishers will now have to apply quarterly for licences to import specified quantities of named books, and giving in each case the name of the exporting country.

There are some observations on such a scheme which immediately come to mind. First there is the vexatious delay in obtaining a necessary book should the British publisher have no copy in stock. Further, in imposing this form of individual licence the Government is in effect instituting a system which might easily become a form of censorship. A. more immediate objection is that the present scheme is based on money value, and takes no account of the increase in book production costs. So far as American books are concerned, prices are 50 per cent and more above the pre-war figure for corresponding books. In effect, therefore, the number of scientific and technical books of American origin it will be possible to import into Britain will be substantially less than the figure for 1939 .

It is becoming generally accepted that the utmost efficiency is necessary in the scientific and technical fields to enable Britain to recover its position in the world. Yet by cutting down supplies of the essential books, the Government is putting an important obstacle in the path; and this at a time when there is an acute shortage of school and university textbooks and also of standard works of reference. It may be urged that some American text-books are not suited for the courses in British schools and universities, but that argument cannot be applied to research monographs and reference works; these, with the all-important specialist periodicals, are essential tools for the scientific worker trying to keep abreast of modern developments.

While it must be granted that restrictions on general expenditure are necessary, it would seem that scientific and technical books should have a high priority in the permissible expenditure of dollars; and it should be possible to devise a scheme whereby such books are made more readily available. 